\title{
Composition and nutritive value of diets consumed by strict vegetarians
}

\author{
By K. GUGGENHEIM, Y. WEISS AND M. FOSTICK \\ Laboratory of Nutrition, Department of Biochemistry, Hebrew University- \\ Hadassah Medical School, ferusalem, Israel
}

(Received 4 Fanuary 1962-Revised 28 March 1962)

The population in technically developed countries generally subsists on a mixed diet. Its pattern of food consumption is varied and almost every meal consists of foods of both animal and vegetable origin. This diversity of food sources is often thought to be a requisite of a 'well-balanced' diet, providing all nutrients in adequate amounts. A satisfactory diet can also be obtained on a strictly vegetarian régime, but a careful selection of foods is necessary to furnish all nutrients and particularly the essential amino acids in sufficient amounts and right proportions, and even a well-selected vegetarian diet is likely to be deficient in vitamin $B_{12}$ (Wokes, Badenoch \& Sinclair, 1955; Halsted, Carroll, Dehghani, Loghmani \& Prasad, 1960), which is lacking in vegetable foods. In most of the developed countries there are small groups of people who adhere, for reasons of conviction, to a strictly vegetarian diet. Though very conscious of the kinds and origin of the foods they eat, they do not generally select them according to scientific principles. Moreover, food fads, and strange beliefs concerning the value of certain foods, are frequently encountered in these groups.

It therefore seemed of interest to study the composition and nutritive value of the diets of strict vegetarians living in a country-Israel-where normally the pattern of food consumption is mixed. The diets of 119 strict vegetarians were studied and the protein value of a composite dietary sample was assessed in experiments with rats.

\section{EXPERIMENTAL}

The dietary survey was made from the beginning of July to the end of September I960. It covered eighty households and included I 9 persons in Jerusalem, Tel-Aviv, and some smaller places. The names and addresses of the vegetarian families were supplied by the Israeli Vegetarian Association. Only families and persons who were strict vegetarians and willing to co-operate were selected for the survey. Most belonged to the urban middle class. Thirty-three families lived in a vegetarian village and were engaged in various agricultural occupations. The mean number of persons per household was small $\left(\mathrm{I}^{\cdot} 5\right)$, because in most families only a few persons adhered to a strict vegetarian diet. Only their diets were studied. Of the households fifty-nine contained one person subsisting on a vegetarian diet, fourteen households contained two, and one, three, one and two households included three, four, five and six vegetarians, respectively. The composition of the sample is shown in Table $\mathbf{r}$. 
Forms for recording daily food consumption were distributed to the families. All foods eaten by the vegetarian members of the families during I week, and their quantities in household measures, were recorded on these forms for each meal and each 'between-meal' period. These quantities were carefully checked by one of us (Y.W.), who visited each family thrice during the study, compared the measures in each household with standard spoons and cups, interviewed the families and helped in completing the forms.

Table I. Composition of the sample of Israeli vegetarians studied

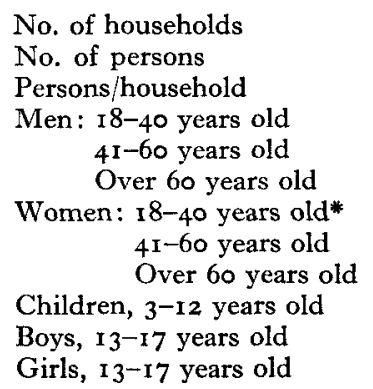

80
119
$1 \cdot 5$
$22(18 \%)$
$33(28 \%)$
$8(7 \%)$
$13(11 \%)$
$25(21 \%)$
$4(3 \%)$
$8(7 \%)$
$4(3 \%)$
$2(2 \%)$

* One woman lactating.

The detailed entries were tabulated on standard calculation sheets. Nutritive values were calculated from a specially prepared table which was in general derived from the tables of Platt (1945), Watt \& Merrill (1950) and Albritton (1954). The vitamin and mineral contents of vegetables and fruits were calculated from the values of Halevy, Koth \& Guggenheim (1957), which are based on analyses of locally grown products. Representative samples of some unusual foods, for which no values are given in the tables, were analysed in our laboratory. Corrections for vitamin losses in cooking were based on the findings of Moore, Purdy, Gibbens, Hollinger \& Goldsmith (1947).

The mean daily consumption of nutrients by the vegetarian members of each family was compared with the recommended dietary allowances of the (USA) National Research Council: Food and Nutrition Board (1958). Intake per unit was computed according to these allowances, men I $8-40$ years old being considered as one unit. A difficulty arose in calculating nicotinic acid equivalents since they represent both preformed nicotinic acid and tryptophan. A representative diet of the population sample was constructed, as described below, and its tryptophan content per $g$ protein was determined, $60 \mathrm{mg}$ tryptophan being considered equivalent to I mg nicotinic acid. The value found was $5.9 \mathrm{mg}$ tryptophan/g protein, and this figure was used for calculation of the nicotinic acid equivalent of each diet.

For determination of the nutritive value of the protein an experimental diet was constructed from the pattern of the average diet (Table 2) and its protein efficiency ratio determined with twelve young male rats in a 4-week assay (Osborne, Mendel \& Ferry, 1919). Cereals were represented in this diet by dried ground bread $(25 \%$ white and $75 \%$ brown), pulses by groundnut flour extracted with diethyl ether, nuts and seeds by similarly extracted sunflower and sesame meals, and potatoes, fruits and 
vegetables by dehydrated potato, beet and carrot powders. Care was taken that each protein source was represented in the rat diet in the same proportion as in the human diet (Table 2). Thus, $33 \%$ of the total protein was derived from bread, $22 \%$ from groundnut flour, $12 \%$ each from sunflower- and sesame-seed meals, and $7 \%$ each from potatoes, beets and carrots. Since in the average vegetarian diet II \% of the calories was derived from protein, the experimental diet was adapted to contain approximately the same percentage of protein. It was appropriately diluted with a protein-free diet consisting of maize starch 45 , dextrose 46 , vegetable oil 5 , salts (USP XIV) 4 parts and the usual vitamins. Thus, the experimental diet was composed of $(\mathrm{g} / \mathrm{kg})$ : dried bread 270, groundnut flour 52, sunflower-seed meal 29, sesame-seed meal 33 , dehydrated potatoes 95 , dehydrated carrots 64 , dehydrated beets 82 , proteinfree diet 375. A diet containing skim-milk powder furnishing the same amount of protein served as control. The amounts of lysine, methionine and tryptophan, which limit the nutritive value of most vegetable proteins (Waterlow \& Stephen, 1957), were determined microbiologically in the diet. For lysine and methionine determinations Leuconostoc mesenteroides P-6o (Steele, Sauberlich, Reynolds \& Baumann, 1949) was used and for tryptophan Lactobacillus arabinosus (Barton-Wright, 1952).

\section{RESULTS}

Food consumption pattern. Table 2 shows the mean daily food consumption per head. The average daily menu provided moderate quantities of cereals, fats and oils, and sugar and sweets, ample amounts of pulses, seeds and nuts and large quantities of fruits and vegetables. Dark and whole-wheat bread amounted to approximately $75 \%$

\section{Table 2. Mean daily food consumption ( $g$ as purchased) of Israeli vegetarians}

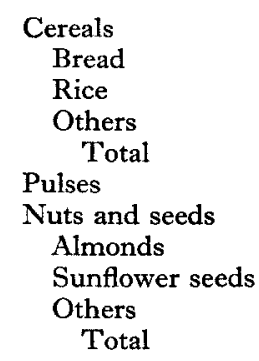

Fats and oils

Fruits and vegetables
Potatoes
Tomatoes
Grapes
Water melons
Musk melons
Prickly pears
Others
Total
Sugar and sweets
Miscellaneous

34

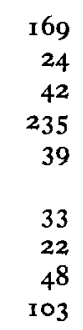

of the total bread eaten, which contrasts with the strong preference for white bread shown by the Israeli population in general. In a recent survey (Bavly, I960), comprising 7000 families of the urban wage-earning population, the mean daily bread consumption amounted to $\mathrm{I} / 7 \mathrm{~g}$ dark bread and $\mathrm{I} 9 \mathrm{I} \mathrm{g}$ white bread. The vegetarians consumed more nuts and seeds than the general population. In Bavly's survey the daily consumption amounted to $5 \mathrm{~g} /$ person, as against $103 \mathrm{~g}$ eaten by the vegetarians. Although the kinds of fruits and vegetables consumed varied with the season in which the survey was performed, the amounts generally eaten were large and by some 
subjects particularly so. Fifty-four persons consumed daily during the week of the investigation $400-1800 \mathrm{~g}$ (mean $660 \mathrm{~g}$ ) grapes, ten persons $400-1000 \mathrm{~g}\left(55^{\circ} \mathrm{g}\right)$ musk melons, ten persons $500-2500 \mathrm{~g}(8 \mathrm{IO} \mathrm{g})$ water melons, nine persons $400-215^{\circ} \mathrm{g}$ $(7 \mathrm{rog})$ cactus figs, five persons $45^{\circ}-65^{\circ} \mathrm{g}\left(54^{\circ} \mathrm{g}\right)$ green figs and four persons $420-$ $640 \mathrm{~g}(5 \mathrm{IO} \mathrm{g})$ tomatoes. Uncommon foods, such as sesame seeds, flax seeds, ground carobs, seaweed, bran, wheat germ and dried yeast, were eaten by many subjects in large amounts.

Nutritional value of diets. The food habits of the vegetarians are reflected in the nutritive value of the diets. Table 3 shows the average consumpton of nutrients per person and the contribution of various food groups to the total supply of nutrients. Cereals provided $40-50 \%$ of the riboflavin and nicotinic acid, one-third of the protein and thiamine and $25-29 \%$ of the calories, calcium and iron. All flour milled in Israel is enriched with $30 \mathrm{~g}$ fat-extracted soya-bean meal, $2.5 \mathrm{~g}$ calcium carbonate and $2.5 \mathrm{mg}$ riboflavin per $\mathrm{kg}$. Pulses furnished $22 \%$ of the protein. Nuts and seeds supplied one-

Table 3. Mean daily consumption of nutrients, and percentage contribution of various food groups to the total supply of nutrients in Israeli vegetarian diets

\begin{tabular}{|c|c|c|c|c|c|c|c|c|}
\hline \multirow[b]{2}{*}{ Nutrient } & \multirow[b]{2}{*}{$\begin{array}{l}\text { Mean daily } \\
\text { consumption }\end{array}$} & \multicolumn{7}{|c|}{ Percentage of total obtained from } \\
\hline & & Cereals & Pulses & $\begin{array}{c}\text { Nuts } \\
\text { and } \\
\text { seeds }\end{array}$ & $\begin{array}{l}\text { Fats } \\
\text { and } \\
\text { oils }\end{array}$ & $\begin{array}{l}\text { Fruits } \\
\text { and } \\
\text { vege- } \\
\text { tables }\end{array}$ & $\begin{array}{l}\text { Sugar } \\
\text { and } \\
\text { sweets }\end{array}$ & Miscellaneous \\
\hline Calories & $2410 \mathrm{kcal}$ & 29 & 7 & I6 & 12 & 32 & 4 & - \\
\hline Protein & $65.5 \mathrm{~g}$ & 33 & 22 & 23 & - & $2 I$ & - & $\mathbf{I}$ \\
\hline Calcium & $825 \mathrm{mg}$ & 23 & 12 & 34 & - & 30 & $\mathbf{I}$ & 一 \\
\hline Iron & $21 \cdot 2 \mathrm{mg}$ & 23 & II & 21 & - & 44 & 一 & $\mathbf{I}$ \\
\hline Vitamin A & 7289 i.u. & - & $\mathbf{r}$ & 一 & 2 & 97 & - & - \\
\hline Thiamine & $2.13 \mathrm{mg}$ & 34 & 9 & 22 & - & 34 & - & $\mathbf{I}$ \\
\hline Riboflavin & $\mathrm{I} \cdot 35 \mathrm{mg}$ & 42 & 7 & 18 & - & 32 & 一 & $\mathbf{I}$ \\
\hline Nicotinic acid & $16.4 \mathrm{mg}$ & 45 & I I & 6 & - & 37 & - & $\mathbf{I}$ \\
\hline Ascorbic acid & $201 \mathrm{mg}$ & - & 一 & - & - & 100 & - & - \\
\hline
\end{tabular}

Table 4. Mean daily consumption of nutrients per consumption unit by Israeli vegetarians

\begin{tabular}{|c|c|c|c|c|c|c|c|c|c|}
\hline & $\begin{array}{c}\text { Calories } \\
\text { (kcal) }\end{array}$ & $\begin{array}{l}\text { Protein } \\
\text { (g) }\end{array}$ & $\begin{array}{l}\text { Calcium } \\
\text { (mg) }\end{array}$ & $\begin{array}{l}\text { Iron } \\
\text { (mg) }\end{array}$ & $\begin{array}{c}\text { Vitamin } \\
\text { A } \\
\text { (i.u.) }\end{array}$ & $\begin{array}{c}\text { Thiamine } \\
(\mathrm{mg})\end{array}$ & $\begin{array}{l}\text { Ribo- } \\
\text { flavin } \\
\text { (mg) }\end{array}$ & $\begin{array}{l}\text { Nicotinic } \\
\text { acid } \\
\text { equi- } \\
\text { valent* } \\
\text { (mg) }\end{array}$ & $\begin{array}{c}\text { Ascorbic } \\
\text { acid } \\
(\mathrm{mg})\end{array}$ \\
\hline Mean & 2895 & $67 \cdot 5$ & 789 & $19 \cdot 6$ & 8015 & $2 \cdot 52$ & $I \cdot 43$ & $25^{\circ} 9$ & 222 \\
\hline $\begin{array}{c}\text { Percentiles } \\
75 \% \\
50 \% \\
25 \%\end{array}$ & $\begin{array}{l}3300 \\
2735 \\
2355\end{array}$ & $\begin{array}{l}78 \cdot 8 \\
63 \cdot 6 \\
52 \cdot 8\end{array}$ & $\begin{array}{l}970 \\
728 \\
554\end{array}$ & $\begin{array}{l}23.5 \\
19.3 \\
15.0\end{array}$ & $\begin{array}{l}9376 \\
6517 \\
4932\end{array}$ & $\begin{array}{l}2 \cdot 86 \\
2 \cdot 36 \\
r \cdot 96\end{array}$ & $\begin{array}{l}I \cdot 65 \\
I \cdot 32 \\
I \cdot O I\end{array}$ & $\begin{array}{l}31 \cdot 4 \\
23 \cdot 5 \\
19 \cdot 2\end{array}$ & $\begin{array}{l}266 \\
205 \\
150\end{array}$ \\
\hline $\begin{array}{l}\text { Mean as per- } \\
\text { centage of re- } \\
\text { commended } \\
\text { dietary } \\
\text { allowancet }\end{array}$ & $\begin{array}{l}\text { See p. } \\
\text { (USA }\end{array}$ & B. & 95 & r96 & 160 & 157 & 79 & 123 & 296 \\
\hline
\end{tabular}


third of the calcium and approximately one-fifth of the protein, iron, thiamine and riboflavin. Fruits and vegetables provided almost all the vitamin $\mathrm{A}$ and vitamin $\mathrm{C}$, $44 \%$ of the iron and about one-third of the calories, thiamine, riboflavin and nicotinic acid. Fats and oils and sugar and sweets, sources of 'empty calories', played a minor part in the diets studied, furnishing only $16 \%$ of total calories. Vitamin A-enriched margarine contributed a small percentage (2) of the total supply of this vitamin; it was used by some vegetarians unaware that the margarine was fortified with a vitamin $\mathrm{A}$ concentrate derived from animal sources.

Table 5. Nutritional value of vegetarian diets in eighty Israeli households: percentage of diets whose nutrients attained the stated proportions of the dietary allowances recommended by the (USA) National Research Council: Food and Nutrition Board (1958)*

\begin{tabular}{|c|c|c|c|c|c|c|c|c|c|}
\hline $\begin{array}{c}\text { Percentage } \\
\text { of } \\
\text { allowance }\end{array}$ & Calories & Protein & Calcium & Iron & $\begin{array}{c}\text { Vitamin } \\
\mathrm{A}\end{array}$ & Thiamine & $\begin{array}{l}\text { Ribo- } \\
\text { flavin }\end{array}$ & $\begin{array}{l}\text { Nicotinic } \\
\text { acid } \\
\text { equi- } \\
\text { valent* }\end{array}$ & $\begin{array}{c}\text { Ascorbic } \\
\text { acid }\end{array}$ \\
\hline 100 or more & 28 & 40 & 40 & 91 & 75 & 88 & 20 & 65 & 99 \\
\hline $80-99$ & $3 \mathbf{I}$ & 26 & 21 & 9 & 9 & 7 & 20 & 21 & - \\
\hline $60-79$ & 30 & 23 & 21 & - & 9 & 5 & $3 \mathrm{I}$ & 9 & $\mathbf{I}$ \\
\hline $50-59$ & Io & 4 & 8 & - & 2 & - & I3 & 4 & - \\
\hline$<50$ & $\mathbf{I}$ & 7 & Io & 一 & 5 & - & 16 & I & - \\
\hline
\end{tabular}

Table 6. Protein efficiency ratio of, and amounts ( $\mathrm{mg} / \mathrm{g}$ nitrogen) of lysine, methionine and tryptophan in the proteins of an average Israeli vegetarian diet and in milk proteins

$\begin{array}{lcccc} & \begin{array}{c}\text { Protein } \\ \text { efficiency } \\ \text { ratio }\end{array} & \text { Lysine } & \text { Methionine } & \text { Tryptophan } \\ \text { Protein source } & \mathbf{1 \cdot 2 7} & 375 & 89 & 37 \\ \text { Vegetarian diet } & \mathbf{2} \cdot 03 & \mathbf{5 2 1} & 161 & 72 \\ \text { Milk proteins } & & \end{array}$

Information on consumption of nutrients per consumption unit is presented in Table 4, which shows that the consumption of almost all nutrients was satisfactory or abundant. Only that of riboflavin, which is contained mainly in animal foods, was somewhat low in spite of the enrichment of flour, whereas that of iron, vitamin A, thiamine and ascorbic acid was high. Table 5 shows the percentage of diets attaining different proportions of the recommended allowances. It can be seen that almost all diets provided $80 \%$ or more of the recommended amounts of iron, thiamine and ascorbic acid, and over two-thirds attained these proportions of protein, vitamin A and nicotinic acid equivalents. The percentage of diets with less than $60 \%$ of the recommended allowance was 29 for riboflavin, 18 for calcium, II for calories and protein, 7 for vitamin A and 5 for nicotinic acid equivalent.

Nutritional value of proteins. The results are given in Table 6 . It can be seen that the protein efficiency ratio of the average vegetarian diet and its contents of lysine, methionine and tryptophan were all much lower than those of a diet containing milk proteins in similar amounts. 


\section{DISCUSSION}

The values presented above show that the composition of the vegetarian diet differed considerably from that of the diet of the general population. Within recent years the food habits and food composition of two groups in the Israeli population have been studied by one of us (Guggenheim \& Dreyfuss, 1959; Guggenheim, Ilan, Vago \& Mundel, 1960). In comparison with these groups the vegetarians used much less bread and other cereals and somewhat less sugar and sweets. On the other hand, they consumed more pulses, nuts and seeds, and fruits and vegetables. In spite of the lack of animal products, their diet was varied and not necessarily monotonous. It is true that many vegetarians exhibited a pronounced predilection for certain foods, e.g. sesame seeds, seaweed, bran, or certain fruits and vegetables which were sometimes consumed in enormous quantities, but the total number of food items appearing in the vegetarian menus was not smaller than that found in mixed diets.

The variety of different foods, the preference for wheat products of low extraction rate and the relatively small amounts of 'empty calories' contributed to the high nutritive value of most of the vegetarian diets. Moreover, some highly nutritious foods were consumed by vegetarians in higher amounts than by the general population. Thus, sesame seeds and their products are rich sources of calcium (Carter, Cirino \& Allen, 196r), iron, thiamine and nicotinic acid, wheat germ and bran of iron and B-vitamins, groundnuts of nicotinic acid, soya beans of calcium, iron and thiamine, chick peas of iron and thiamine and dried yeast of B vitamins. Large amounts of carotene were obtained from carrots, spinach and other leafy vegetables and ascorbic acid from green peppers and guava. As a result of these dietary habits, almost all nutrients were present in adequate amounts in most diets. Even without milk and milk products, calcium consumption attained a mean daily level of $825 \mathrm{mg} /$ person, or $95 \%$ of the recommended allowance. Only riboflavin was present in many diets in inadequate amounts.

Hardinge \& Stare (1954) studied the diets of twenty-seven strict vegetarians in the USA. These persons consumed cereals, legumes, nuts and seeds and large quantities of vegetables. The average diet supplied most nutrients in sufficient amounts, a few subjects having less protein, calcium and riboflavin than the recommended dietary allowances. The vegetarian diet was rich in iron, thiamine and vitamins $\mathrm{A}$ and $\mathrm{C}$; it contained less calories, protein, calcium and riboflavin than the diets of comparable non-vegetarians, but similar amounts of nicotinic acid.

Although the consumption of protein by our vegetarians was adequate from a quantitative point of view, the nutritional quality of the dietary protein was rather low. The protein efficiency ratio was only $\mathrm{I} \cdot 27$, considerably lower than those of two diets ( $\mathrm{r} \cdot 76$ and $\mathrm{r} \cdot 93)$ consumed by middle-class Israelis (Guggenheim, unpublished). It is, however, interesting that the limiting amino acid in the vegetarian diet appeared not to be lysine, which limits the nutritive value of the proteins in both low-income and middle-class Israeli diets (Guggenheim, 196r). Whereas the latter contain 231279 and $248-3$ r $9 \mathrm{mg}$ lysine/g nitrogen respectively, $375 \mathrm{mg}$ lysine/g nitrogen were found in the average vegetarian diet. This high figure was probably due to the high 
consumption of pulses, nuts and seeds and the low consumption of cereals. Cereals provided 68 and $50 \%$ of the total protein in the low-income and middle-class diets mentioned above as against $33 \%$ in the vegetarian diet. Moreover, the lysine content of the mixed proteins of the average vegetarian diet $(375 \mathrm{mg} / \mathrm{g}$ nitrogen) was higher than that $(270 \mathrm{mg} / \mathrm{g}$ nitrogen) recommended by FAO (1957). In contrast, methionine and tryptophan were present in the vegetarian proteins in low concentrations. The proteins contained $89 \mathrm{mg}$ methionine and $37 \mathrm{mg}$ tryptophan/g nitrogen as against $\mathrm{I} 44$ and $90 \mathrm{mg}$ recommended by FAO (1957).

It may be of value to compare our figures with those of a diet of English vegetarians as recently reported by Hughes (1959). This diet contained $269 \mathrm{mg}$ lysine, $75 \mathrm{mg}$ methionine and $57 \mathrm{mg}$ tryptophan/g nitrogen. Whereas lysine was found to be the critical amino acid in the proteins of mixed diets (Guggenheim, 196r), it appears that in the vegetarian diets studied by us other amino acids, possibly methionine or tryptophan, limit the nutritional value of the proteins.

\section{SUMMARY}

I. The composition and nutritional value of the diets of I I 9 strict vegetarians living in eighty households were studied during $\mathbf{I}$ week. The mean daily consumption of food/head amounted to $235 \mathrm{~g}$ bread and other cereals, $39 \mathrm{~g}$ pulses, 103 $\mathrm{g}$ nuts and seeds, $34 \mathrm{~g}$ oils and fats, $\mathrm{I} 7 \mathrm{I} 8 \mathrm{~g}$ fruits and vegetables and $3 \mathrm{r} \mathrm{g}$ sugar and sweets. This average menu furnished $2410 \mathrm{kcal}, 65 \cdot 5 \mathrm{~g}$ protein, $825 \mathrm{mg}$ calcium, $21 \cdot 2 \mathrm{mg}$ iron, 7289 i.u. vitamin $A, 2 \cdot 13 \mathrm{mg}$ thiamine, $1 \cdot 35 \mathrm{mg}$ riboflavin, $16 \cdot 4 \mathrm{mg}$ nicotinic acid and $201 \mathrm{mg}$ ascorbic acid.

2. The general level of consumption of nutrients was satisfactory, but the riboflavin content of $29 \%$ of the eighty diets studied was definitely inadequate compared with the (USA) National Research Council's recommended allowances.

3. The nutritional value of the protein mixture of an average vegetarian diet, assessed on young rats, was found to be low. The mixture was deficient in methionine and tryptophan, whereas the content of lysine appeared to be satisfactory.

\section{REFERENCES}

Albritton, E. C. (editor) (1954). Standard Values in Nutrition and Metabolism. London and Philadelphia: W. B. Saunders Co.

Barton-Wright, E. C. (1952). The Microbiological Assay of the Vitamin B-Complex and Amino Acids. London: Sir Isaac Pitman and Sons, Ltd.

Bavly, S. (1960). Food Consumption and Levels of Nutrition of Urban Wage and Salary Earners' Families in Israel. Jerusalem: Central Bureau of Statistics.

Carter, F. L., Cirino, V. O. \& Allen, L. E. (196r). F. Amer. Oil Chem. Soc. 38, I48.

F.A.O. (1957). FAO nutr. Stud. no. I6.

Guggenheim, K. (1961). Bull. Res. Coun. Israel, 9E, 159.

Guggenheim, K. \& Dreyfuss, F. (1959). Amer. F. clin. Nutr. 7, 519.

Guggenheim, K., Ilan, J., Vago, T. \& Mundel, G. (1960). Brit. F. Nutr. 14, 347.

Halevy, S., Koth, H. \& Guggenheim, K. (1957). Brit. F. Nutr. II, 409.

Halsted, J. A., Carroll, J., Dehghani, A., Loghmani, M. \& Prasad, A. S. (r960). Amer. F. clin. Nutr. 8, 374 .

Hardinge, M. G. \& Stare, F. J. (1954). Amer. F. clin. Nutr. 2, 73.

Hughes, B. P. (1959). Brit. F. Nutr. 13, 330.

Moore, M. C., Purdy, M. B., Gibbens, E. J., Hollinger, M. E. \& Goldsmith, G. (1947). F. Amer. diet. Ass. 23, 847 . 
National Research Council: Food and Nutrition Board (1958). Publ. nat. Res. Coun., Wash., no. 589.

Osborne, T. B., Mendel, L. B. \& Ferry, E. L. (1919). F. biol. Chem. 37, 223.

Platt, B. S. (1945). Spec. Rep. Ser. med. Res. Coun., Lond., no. 253.

Steele, B. F., Sauberlich, H. E., Reynolds, M. S. \& Baumann, C. A. (1949). F. biol. Chem. 177, 533.

Waterlow, J. C. \& Stephen, J. M. L. (editors) (1957). Human Protein Requirements and their Fulfilment in Practice. Proceedings of a Conference in Princeton, U.S.A., 1955, p. 145. New York: FAO/WHO/ Josiah Macy Jr. Foundation.

Watt, B. K. \& Merrill, A. L. (1950). U.S. Dep. Agric. Handb. no. 8.

Wokes, F., Badenoch, J. \& Sinclair, H. M. (r955). Amer. F. clin. Nutr. 3, 375. 